\title{
Mandibular Pre-Molars Endodontic Anatomy and Role in Sex Dimorphism for Western Asia Population Using CBCT 3D Imaging Technique
}

\author{
Anatomía Endodóntica de Premolares Mandibulares y Papel en el Dimorfismo Sexual \\ para la Población de Asia Occidental Utilizando la Técnica de Imagen 3d CBCT
}

Zeeshan Qamar ${ }^{1,2}$; Salah Abdalkreem Almohana ${ }^{1}$; Alhanouf Abdulkarem Almohana ${ }^{1}$; Saleh Alghufaili ${ }^{1}$ \& Tayyaba Zeeshan $^{3}$

QAMAR, Z.; AlMOHANA, S. A.; ALMOHANA, A. A.; ALGHUFAILI, S. \& ZEESHAN, T. Mandibular pre-molars endodontic anatomy and role in sex dimorphism for western asia population using cbct 3d Imaging Technique. Int. J. Morphol., 39(6):1554-1558, 2021.

SUMMARY: Cone Beam Computerized Tomography (CBCT) imaging technique can be used for identifying the root canal anatomy and its use in determining sexual dimorphism. The aim of current study was to identify the commonly found root canal morphology and gender dimorphism for mandibular pre-molars in Western Asia population according to Vertucci's classification using CBCT 3D imaging technique. On ethical approval 470 patients from Western Asia population with intact healthy mandibular first and second premolars were included in the study. The selected patients were sent to radiology department of Riyadh Elm University, Saudi Arabia for CBCT images. The observations recorded included: i) number of roots; and ii) type of root canal morphology based on Vertucci's classification. All the mandibular first and second pre-molars had single root both in males and females. The type of Vertucci's classification commonly observed was Type I both in males $(88.94 \%)$ and females $(100 \%)$ in mandibular first pre-molars. Similarly Type I was identified as a common root canal configuration in mandibular second pre-molars for males $(82.77 \%)$ and females (100\%). The two canal configurations Type IV and V were only observed in the males. It can be concluded from the results mandibular first and second pre-molars in the Western Asia population are single rooted with common Vertucci's Type I canal configuration in the females with rare evidence of two canals in males. Additionally CBCT is an effective technique and should be used for detection of root canals in the mandibular pre-molars which can aid dentists in providing a successful endodontic therapy.

KEY WORDS: Cone beam computed tomography; Mandibular first pre-molar; Mandibular second pre-molar; Root canals; Vertucci's classification.

\section{INTRODUCTION}

A successful endodontic therapy is based on the root canal morphology. The roots and the endodontic morphology varies between the teeth therefore a comprehensive knowledge regarding its anatomic dissimilarities may play a vital role in helping the clinicians to identify and perceive these deviations during endodontic therapy as ignorance which might lead to failure in treatment (Zillich \& Dowson, 1973; Alrahabi \& Zafar, 2015). The endodontic anatomy may vary in a different ethnic or regional population (Amos, 1955; Vertucci, 1978; Dinakar et al., 2018). Therefore, it is essential to be aware of deviations in tooth morphology \& distinguishing features in different ethnic groups, as such information can assist in locating, negotiating \& managing the canals (Velmurugan \& Sandhya, 2009). In short, it can be suggested that the original geometry of a canal, before shaping \& cleaning procedures, has more influence on the changes, which occurred during preparation, than the instrumentation technique itself (Vertucci, 2005).

The conventional and affordable commonly used 2D imaging technique, like the peri-apical radiographs are typically used in dental practice to evaluate the pathway of root canals (Al-Nazhan et al., 2012). Thus it leads to missing accessory canals and other structures causing failure of endodontic therapy (Zhang et al., 2017). The competent

\footnotetext{
${ }^{1}$ Department of OMFS and Diagnostic Sciences, Faculty of Dentistry, Riyadh Elm University, Riyadh, Saudi Arabia.

${ }^{2}$ Department of Oral Biology, Liaquat College of Medicine and Dentistry,Karachi, Pakistan.

${ }^{3}$ Department of Oral \& Craniofacial Sciences, University Malaya, Malaysia.
} 
calculation of the anatomic morphology before performing endodontic treatment should use the most precise imaging system. Various systems have been employed to study the internal anatomy of teeth in three dimensions including clearing and staining canal technique (Robertson et al., 1980), cone beam computed tomography (CBCT) (Neelakantan et al., 2010a), digital and contrast mediumenhanced radiographic techniques (Neelakantan et al., 2010b), scanning electron microscope (SEM) (Heard \& Walton, 1997) and micro-computed radiography (Verma \& Love, 2011).

The CBCT is a non-invasive and sensitive technique providing 3D image of an entire tooth and its supporting structures (Yu et al., 2012). It is very a valuable in dentomaxillofacial imaging technique. CBCT scanning was introduced in the 1990s and has been reported having many dental applications, including morphologic analysis (Sherrard et al., 2010).

The root canal configuration variation is influenced by various genetic factors. The individuals from Asian continent present variations in the canal shape, root form externally and canal space morphology internally (Singh $\&$ Pawar, 2015). The root canal system is intricate and as the canal may branch, divide and re-join taking various pathways to the apex. Many classification systems and modifications have been introduced but till-date Vertucci's system remains the most reliable method to identify the anatomical variations in the root canal system of different teeth. Vertucci's identified eight pulp canal configurations (Vertucci, 1984).

Till date various studies have been conducted identifying root canal morphology based on the Vertucci's classification in incisors (Kartal \& Yanikoglu 1992; Leoni et al., 2014), canines (Amardeep et al., 2014; Soleymani et al., 2017), premolars (Vertucci \& Gegauff, 1979; Cleghorn et al., 2007) and molars (Sidow et al., 2000; Cleghorn et al., 2006). The molars of the maxillary arch are the most commonly studied teeth due to their multi-rooted nature and difficulty in treatment (Zhang et al., 2011). The premolars of maxillary arch are multi-rooted, whereas those in the mandibular arch are generally considered to have a single root with one canal. In most of the studies it is observed that mandibular premolars are single rooted, however, presence of radicular grooves and depressions at different levels may produce an appearance of multi-rooted teeth and presence of multiple canals (Boschetti et al., 2017). The premolars demonstrate the most variations in the root canal anatomy, which is a contributory factor of root canal failure (Jain \& Bahuguna, 2011). Trope et al. (1986) studied the morphological variations of root canal in root canal in different racial groups and they reported a higher incidence of two or more canals in black patients $(32.8 \%)$ in comparison to white patients $(13.7 \%)$. In another study a $76 \%$ incidence of one canal and $24 \%$ incidence of two canals has been reported (Baisden et al., 1992). In a study conducted on Chinese population reported an incidence of single root and single canal in $54 \%$ mandibular first premolars, two canals were reported in 22 $\%$ of mandibular first premolars and circumferential canals were reported in $24 \%$ of the subjects (Lu et al., 2006). Additionally, Wu et al. (2020) also reported an incidence of $58.2 \%$ to $88.5 \%$ single-rooted canals with Type I classification, variations exist in different regions and races. Till date none of the studies have been reported related to the endodontic anatomy of premolars in the mandibular arch for Western Asia population.

The main aim of the study was to evaluate the commonly found root canal morphology and gender dimorphism for mandibular premolars in Western Asia population according to Vertucci's classification using CBCT.

\section{MATERIAL AND METHOD}

The convenience sampling technique was used to recruit 470 patients on written consent after ethical approval from Institutional Review Board of Riyadh Elm University. The patients included were aged between 18-30 years with completely developed roots of the mandibular pre-molars. Whereas the exclusion criterion set for the patients not to be included was distorted radiographic images, pre-molars with restorations, endodontically treated, resorbed roots, calcified roots, peri-apical abscess, carious, fractured, hyper-cementosis, resorbed bone, vitamin D deficiency and bony pathologies.

Procedure. The patients reported to Dental OPD of Riyadh Elm University, Saudi Arabia were recruited based on the inclusion and exclusion criterions. The patients were explained in detail about the steps involved in the procedure of CBCT. After taking detailed medical and dental history, on written consent the patients were referred to the radiology department of University for CBCT images.

Prior to $\mathrm{CBCT}$ imaging the patients were provided with neck collar and aprons made of lead. The imaging was conducted following "As low as reasonably achievable" (ALARA) principle for radiation exposure. Later the CBCT images were used to evaluate the number and position of roots. Additionally canal bifurcation and 
endodontic anatomy based on Vertucci's classification was evaluated with the help of 3D planner dental imaging software VILLA version 2.2.1_2019.

The data was analyzed using SPSS software version 19, USA. Chi-Square analysis was carried out between Vertucci's classification of root canal morphology for mandibular first and second premolar, and to identify difference in endodontic anatomy in premolar between males and females. Post hoc Fisher Exact test was used for further detailed comparison.

\section{RESULTS}

The mean age of the participants was $26.2 \pm 5.3$ among which 267 (56.81\%) were males followed by 203 (43.19 $\%$ ) were females. All the participants included had intact mandibular first and second pre molars. The mandibular first pre molars with single canal were approximately $97.44 \%$ $(n=916)$ and $2.56 \%(n=24)$ with two canals, additionally the mandibular second pre-molars with single canal were
$98.30 \%(\mathrm{n}=924)$ and $1.70 \%(\mathrm{n}=16)$ with two canals. Two canals were observed in the male patients only. All the mandibular pre-molars were observed to be single rooted.

The Chi-square test with Fisher's post hoc test was applied to evaluate the association between mandibular first and second molars of both sides respectively. Vertucci's Type I root canal anatomy was most commonly observed in both mandibular first and second pre-molars trailed by Type V and Type IV. Statistically significant association was observed in the mandibular first and second premolar on the right (p-value <0.001) and left side (p-value <0.001) as displayed in Table I.

The Chi-square with Fisher's post hoc test was applied to evaluate the association of Vertucci's classification between males and females as shown in Table II. For mandibular first pre-molars on right side $87.64 \%$ teeth had Type I configuration, followed by Type V and Type VI configuration in males. Statistically significant differences were observed between right mandibular first premolars of males and females ( $p$-value $=0.016$ ). Similarly the mandibular first pre-molars of left side $90.24 \%$ males teeth had Type I

Table I. Vertucci's endodontic anatomy association between mandibular first and second pre-molars.

\begin{tabular}{cccccccccc}
\hline First Pre- \\
molars
\end{tabular}

*p-value less than $1 \%$ as computed by Fisher's post hoc test

Table II. Association of Vertucci's classification in mandibular first and second pre-molars (both sides) between the males and females.

\begin{tabular}{|c|c|c|c|c|}
\hline \multirow{2}{*}{$\begin{array}{c}\text { Mandibular Pre-molar } \\
\text { Type }\end{array}$} & \multicolumn{3}{|c|}{ Vertucci's Classification } & \multirow[t]{2}{*}{ _ value } \\
\hline & $\begin{array}{l}\text { Type I } \\
\text { n (\%) }\end{array}$ & $\begin{array}{c}\text { Type IV } \\
\text { n (\%) }\end{array}$ & $\begin{array}{c}\text { Type V } \\
\text { n (\%) }\end{array}$ & \\
\hline First pre-molar (Rt) & & & & $0.016^{*}$ \\
\hline Males & $234(87.64 \%)$ & $7(2.62 \%)$ & $26(9.74 \%)$ & \\
\hline Females & $203(100 \%)$ & $0(0 \%)$ & $0(0 \%)$ & \\
\hline Second pre-molar (Rt) & & & & 0.23 \\
\hline Males & $221(82.77 \%)$ & $20(7.49 \%)$ & $26(9.74 \%)$ & \\
\hline Females & $203(100 \%)$ & $0(0 \%)$ & $0(0 \%)$ & \\
\hline First pre-molar (Lt) & & & & $0.01 *$ \\
\hline Males & $241(90.24 \%)$ & $0(0 \%)$ & $26(9.76 \%)$ & \\
\hline Females & $203(100 \%)$ & $0(0 \%)$ & $0(0 \%)$ & \\
\hline Second pre-molar $(L t)$ & & & & 0.23 \\
\hline Males & $221(82.77 \%)$ & $20(7.49 \%)$ & $26(9.74 \%)$ & \\
\hline Females & $203(100 \%)$ & $0(0 \%)$ & $0(0 \%)$ & \\
\hline
\end{tabular}

*p-value significant at $5 \%$ as computed by Fisher's post hoc test. 
endodontic anatomy followed by Type V. But the Type IV root canal morphology was not observed in males. Statistically significant association was found between males and females for the first pre-molars on the left side ( $\mathrm{p}$-value $=0.01$ ).

\section{DISCUSSION}

Our study was conducted to evaluate common root canal configuration based on Vertucci's classification in mandibular premolars of the Western Asia population using CBCT. A total number of 470 patients were included in the study to evaluate endodontic anatomy of the mandibular first and second pre-molars on both sides. The most commonly type of root canal configuration observed was Type I that is a single canal from the start of the pulp chamber to the apical foramen. The next common type that was observed was type $\mathrm{V}$, a single canal starting from the pulp chamber later dividing in two separate canals near apical third of the tooth. The presence of type IV root canal morphology with two canals having separate openings was also observed in our study. Other canal configurations were not observed in this study. Only single rooted mandibular pre-molars were observed in this study although variations have been reported in other studies (Trope et al.; Cleghorn et al., 2008).

The current findings are in accordance with Sobhani Mohhsen et al. (2013) evaluating mandibular first premolars in Iranian population using CBCT and observed type I root canal configuration in approximately $90.8 \%$ participants. Similarly a study conducted in Western China observed mandibular first pre-molars had a common Type I single root canal configuration (87.1\%) followed by type V (Yu et al.). Type I single canal configuration have been detected majorly in the mandibular first pre-molars in approximately $69.3-86$ $\%$ participants, whereas two canals have been reported rarely which is in a strong association to the findings of our study (Green, 1973; Zillich \& Dowson; Vertucci, 1978).

Another group of researchers evaluated the mandibular pre-molars in Turkish Cypriots and observed single canal configuration Type I trailed by V, IV and II as the least common (Celikten et al., 2016). But Cleghorn et al. (2007) reported 24 $\%$ of mandibular first pre-molars have two canals. On the other hand in our study the percentage of mandibular first and second pre-molars with two canals was very low with prevalence in males only. The findings in our study are in accordance with other studies using similar technique.

Significant difference in males and females was observed in mandibular first pre-molars of both right and left sides of the mandibular arch. The results of predict gender dimorphism based on the type of canal configurations. A group of researchers reported gender dimorphism in Turkish population based on the root canal anatomy (Sert \& Bayirli, 2004). In our study females were identified to have a higher prevalence of Type I canal configuration in both types of premolars on each side of the mandibular arch as compared to males.

CONCLUSION. The incidence of a single canal Type I Vertucci's configuration was high in mandibular pre-molars as compared to two canals. Additionally, the two canal configurations Type IV and V are rarely observed but only in the males of Western Asia.

QAMAR, Z.; ALMOHANA, S. A.; ALMOHANA, A. A.; ALGHUFAILI, S. \& ZEESHAN, T. Anatomía endodóntica de premolares mandibulares y papel en el dimorfismo sexual para la población de asia occidental utilizando la técnica de imagen $3 \mathrm{~d}$ cbct. Int. J. Morphol., 39(6):1554-1558, 2021.

RESUMEN: La imagen de la tomografía computarizada de haz cónico (CBCT) se puede utilizar para identificar la anatomía del conducto radicular y para determinar el dimorfismo sexual. El objetivo del estudio fue identificar la morfología del conducto radicular y el dimorfismo de sexo, comúnmente encontrados en los premolares mandibulares en la población de Asia occidental, de acuerdo con la clasificación de Vertucci, utilizando la técnica de imágenes CBCT 3D. Tras la aprobación ética, se incluyeron en el estudio 470 pacientes de la población de Asia occidental con primeros y segundos premolares mandibulares sanos intactos. Los pacientes seleccionados fueron enviados al departamento de radiología de la Universidad de Riyadh Elm, Arabia Saudita, para las imágenes СBCT. Las observaciones incluyeron: i) número de raíces; y ii) tipo de morfología del conducto radicular según la clasificación de Vertucci. Se observó solamente una raíz en los primeros y segundos premolares mandibulares tanto en hombres como en mujeres. El tipo de clasificación de Vertucci comúnmente observado fue Tipo I tanto en hombres $(88,94 \%)$ como en mujeres $(100 \%)$ en los primeros premolares mandibulares. El Tipo I se identificó como una configuración común del conducto radicular en los segundos premolares mandibulares para hombres $(82,77 \%)$ y mujeres $(100 \%)$. Ambas configuraciones de canal Tipo IV y V solo se observaron en los varones. Se puede concluir a partir de los resultados de los primeros y segundos premolares mandibulares en la población de Asia occidental, que éstos tienen una sola raíz con una configuración de canal de Vertucci Tipo I común en mujeres con una evidencia de dos canales infrecuente en los hombres. La CBCT es una técnica eficaz y debe usarse para la detección de conductos radiculares en los premolares mandibulares, lo que puede ayudar a los dentistas a proporcionar una terapia endodóntica exitosa.

KEY WORDS: Tomografía computarizada de haz cónico; Primer premolar mandibular; Segundo premolar mandibular; Endodoncias; Clasificación de Vertucci. 


\section{REFERENCES}

Al-Nazhan, S.; Al-Daafas, A. \& Al-Maflehi, N. Radiographic investigation of in vivo endodontically treated maxillary premolars in a Saudi Arabian subpopulation. Saudi Endod. J., 2(1):1-5, 2012.

Alrahabi, M. \& Zafar, M. S. Evaluation of root canal morphology of maxillary molars using cone beam computed tomography. Pak. J. Med. Sci., 31(2):42630, 2015.

Amardeep, N. S.; Raghu, S. \& Natanasabapathy, V. Root canal morphology of permanent maxillary and mandibular canines in Indian population using cone beam computed tomography. Anat. Res. Int., 2014:731859, 2014.

Amos, E. R. Incidence of bifurcated root canals in mandibular bicuspids. J. Am. Dent. Assoc., 50(1):70-1, 1955.

Baisden, M. K.; Kulild, J. C. \& Weller, R. N. Root canal configuration of the mandibular first premolar. J. Endod., 18(10):505-8, 1992.

Boschetti, E.; Silva-Sousa, Y. T. C.; Mazzi-Chaves, J. F.; Leoni, G. B.; Versiani, M. A.; Pécora, J. D.; Saquy, P. C. \& Sousa, M. D. D. Micro-CT evaluation of root and canal morphology of mandibular first premolars with radicular grooves. Braz. Dent. J., 28(5):597-603, 2017.

Celikten, B.; Orhan, K.; Aksoy, U.; Tufenkci, P.; Kalender, A.; Basmaci, F. \& Dabaj, P. Cone-beam CT evaluation of root canal morphology of maxillary and mandibular premolars in a Turkish Cypriot population. BDJ Open, 2:15006, 2016.

Cleghorn, B. M.; Christie, W. H. \& Dong, C. C. Root and root canal morphology of the human permanent maxillary first molar: a literature review. J. Endod., 32(9):813-21, 2006.

Cleghorn, B. M.; Christie, W. H. \& Dong, C. C. S. Anomalous mandibular premolars: a mandibular first premolar with three roots and a mandibular second premolar with a C-shaped canal system. Int. Endod. J., 41(11):100514, 2008.

Cleghorn, B. M.; Christie, W. H. \& Dong, C. C. The root and root canal morphology of the human mandibular first premolar: a literature review. $J$. Endod., 33(5):509-16, 2007.

Dinakar, C.; Shetty, U. A.; Salian, V. V. \& Shetty, P. Root canal morphology of maxillary first premolars using the clearing technique in a South Indian population: an in vitro study. Int. J. Appl. Basic. Med. Res., 8(3):143-7, 2018.

Green, D. Double canals in single roots. Oral Surg. Oral Med. Oral Pathol., 35(5):689-96, 1973.

Heard, F. \& Walton, R. E. Scanning electron microscope study comparing four root canal preparation techniques in small curved canals. Int. Endod. J., 30(5):323-31, 1997.

Jain, A. \& Bahuguna, R. Root canal morphology of mandibular first premolar in a gujaratipopulation - an in vitro study. Dent. Res. J. (Isfahan), 8(3):118-22, 2011.

Kartal, N. \& Yanikoglu, F. C. Root canal morphology of mandibular incisors. J. Endod., 18(11):562-4, 1992.

Leoni, G. B.; Versiani, M. A.; Pécora, J. D. \& de Sousa-Neto, M. D. Microcomputed tomographic analysis of the root canal morphology of mandibular incisors. J. Endod., 40(5):710-6, 2014.

Lu, T. Y.; Yang, S. F. \& Pai, S. F. Complicated root canal morphology of mandibular first premolar in a Chinese population using the cross section method. J. Endod., 32(10):932-6, 2006.

Neelakantan, P.; Subbarao, C. \& Subbarao, C. V. Comparative evaluation of modified canal staining and clearing technique, cone-beam computed tomography, peripheral quantitative computed tomography, spiral computed tomography, and plain and contrast medium-enhanced digital radiography in studying root canal morphology. J. Endod., 36(9):1547-51, 2010 b.

Neelakantan, P.; Subbarao, C.; Ahuja, R.; Subbarao, C. V. \& Gutmann, J. L. Cone-beam computed tomography study of root and canal morphology of maxillary first and second molars in an Indian population. J. Endod., 36(10):1622-7, 2010a.

Robertson, D.; Leeb, I. J.; Mckee, M. \& Brewer, E. A clearing technique for the study of root canal systems. J. Endod., 6(1):421-4, 1980.

Sert, S. \& Bayirli, G. S. Evaluation of the root canal configurations of the mandibular and maxillary permanent teeth by gender in the Turkish population. J. Endod., 30(6):391-8, 2004.
Sherrard, J. F.; Rossouw, P. E.; Benson, B. W.; Carrillo, R. \& Buschang, P. H. Accuracy and reliability of tooth and root lengths measured on cone-beam computed tomographs. Am. J. Orthod. Dentofacial. Orthop., 137(4 Suppl.):S100-8, 2010.

Sidow, S. J.; West, L. A.; Liewehr, F. R. \& Loushine, R. J. Root canal morphology of human maxillary and mandibular third molars. J. Endod., 26(11):675-8, 2000.

Singh, S. \& Pawar, M. Root canal morphology of South Asian Indian maxillary molar teeth. Eur. J. Dent., 9(1):133-44, 2015.

Sobhani Mohhsen, A.; Razmi, H. \& Sadegh, M. Evaluation of anatomy and morphology of human mandibular premolar teeth by cone-beam computed tomography in Iranian population. J. Dent. Med., 26(3):203-10, 2013.

Soleymani, A.; Namaryan, N.; Moudi, E. \& Gholinia, A. Root canal morphology of mandibular canine in an Iranian population: A CBCT assessment. Iran Endod. J., 12(1):78-82, 2017.

Trope, M.; Elfenbein, L. \& Tronstad, L. Mandibular premolars with more than one root canal in different race groups. J. Endod., 12(8):343-5, 1986.

Velmurugan, N. \& Sandhya, R. Root canal morphology of mandibular first premolars in an Indian population: a laboratory study. Int. Endod. J., 42(1):54$8,2009$.

Verma, P. \& Love, R. M. A Micro CT study of the mesiobuccal root canal morphology of the maxillary first molar tooth. Int. Endod. J., 44(3):210-7, 2011.

Vertucci, F. J. \& Gegauff, A. Root canal morphology of the maxillary first premolar. J. Am. Dent. Assoc., 99(2):194-8, 1979.

Vertucci, F. J. Root canal anatomy of the human permanent teeth. Oral Surg. Oral Med. Oral Pathol., 58(5):589-99, 1984.

Vertucci, F. J. Root canal morphology and its relationship to endodontic procedures. Endod. Top., 10(1):3-29, 2005.

Vertucci, F. J. Root canal morphology of mandibular premolars. J. Am. Dent. Assoc., 97(1):47-50, 1978.

Wu, D.; Hu, D. Q.; Xin, B. C.; Sun, D. G.; Ge, Z. P. \& Su, J. Y. Root canal morphology of maxillary and mandibular first premolars analyzed using cone-beam computed tomography in a Shandong Chinese population. $\mathrm{Me}$ dicine (Baltimore), 99(20):e20116, 2020.

Yu, X.; Guo, B.; Li, K. Z.; Zhang, R.; Tian, Y. Y.; Wang, H. \& Hu, T. Cone-beam computed tomography study of root and canal morphology of mandibular premolars in a western Chinese population. BMC Med. Imaging, 12:18, 2012.

Zhang, D.; Chen, J.; Lan, G.; Li, M.; An, J.; Wen, X.; Liu, L. \& Deng, M. The root canal morphology in mandibular first premolars: a comparative evaluation of cone-beam computed tomography and micro-computed tomography. Clin. Oral Investig., 21(4):1007-12, 2017.

Zhang, R.; Yang, H.; Yu, X.; Wang, H.; Hu, T. \& Dummer, P. M. H. Use of CBCT to identify the morphology of maxillary permanent molar teeth in a Chinese subpopulation. Int. Endod. J., 44(2):162-9, 2011.

Zillich, R. \& Dowson, J. Root canal morphology of mandibular first and second premolars. Oral Surg. Oral Med. Oral Pathol., 36(5):738-44, 1973.

\section{Corresponding author: \\ Dr. Zeeshan Qamar \\ B.D.S, M.Sc, PhD \\ Assistant Professor \\ Department of OMFS and Diagnostic Sciences \\ Riyadh Elm University \\ Riyadh \\ SAUDI ARABIA}

E-mail: zeeshan.qamar@ymail.com

Received: 06-08-2021

Accepted: 28-08-2021 